Journal of Teacher Education for Sustainability, vol. 11, no. 2, pp. 51-63, 2009

\title{
THE QUALITY OF FAMILY RELATIONS IN ENSURING SUSTAINABLE EDUCATION
}

\author{
Monica Sakk, Marika Veisson and Karin Lukk \\ Tallinn University, Estonia
}

\begin{abstract}
Family research is crucially important to teacher education and training because it delivers important insights for understanding the conditions of students' socialisation. Changes in family life, like longer working hours of parents, actual loss of adult company in children's life, less time spent on family activities, have raised the question of quality in family relationships. The current article discusses the main aspects of parental practices: care, control and family activities. The study analysed how students and parents understand family care, joint activities, vision of future and the differences of their conceptions. Two ethnic groups - Estonian and Russian families were studied. The current study was based on a questionnaire, which was administered to 4372 students in grades 4 through 12 of secondary schools and 2405 parents. The results were analysed using $\chi^{2}$-test. The results revealed that students worry about their future coping at school and about finishing the school significantly more than parents. There are differences between two ethnic groups - Estonian and Russian: Russian families tend to have higher levels of care and control than Estonian families and relations between children and parents are closer in Russian families as well. The article provides teachers with useful information to work with families of different ethnic groups.
\end{abstract}

Key words: students; parents; parental practice; care; vision of future.

\section{Introduction}

During the last few decades there have been significant changes concerning the three categories of child's protective environmental factors - family, school, and community (Abelev, 2009). Working life has changed, with work involving manual labour diminishing and mentally strenuous work increasing. The home is becoming a site of evening and weekend work (Stadelmann, Perren, Von Wyl, \& Von Klitzing, 2007).

These changes also have implications for everyday family life. Due to changes in working life and harder competition in the labour market people have less free time to spend with their family; traditional family values and the family itself have eroded; new family forms and competing views of parenting have led to a situation in which the 
concept of the family itself has become more contested; there is an erosion of parenthood that is, a loss of adult company in children's and young people's life. Many of these assumptions suggest that young people also perceive family life as less important and that families actually spend less and less time together. But at the same time the studies show that the role of the family and parents continues to be meaningful in supporting child's sustainable development - the development that ensures child's coping in his/her future life (Turtiainen, Karvonen, \& Rahkonen, 2007).

We think that family research is important to teacher and teacher training because it delivers important insights for understanding the conditions of students' socialisation. Bronfenbrenner (2005) suggests that, in many respects, teachers lack insight into and experience with the complexities of family interactions within their multiple ecological settings. Good sustainable in teacher education is not attainable without considering the moral and personal background of the teachers (Mandolini, 2007). In Estonia the most important key persons in developing children and their families are teachers as the network of social support, the system of social workers does not cover all necessary aspects of a family education. The challenge for teacher educators, therefore, is to help teachers to develop positive, yet realistic dispositions toward working with families (Baum \& Swick, 2008).

\section{The meaning of good parent-child relationships}

The family serves as a major context of socialization for children. One type of influence within this context is the quality of parent-child relationships, which has been linked to children's academic, social and emotional development (Kerns, Aspelmeier, Gentzler \& Grabill, 2006; Stadelmann, Perren, Von Wyl, \& Von Klitzing, 2007). Despite the importance of these relationships, few studies have examined what constitutes good parent-child relationships (Crockett, Brown, Russell, \& Shen, 2007). An explanation from the attachment perspective might be that parental responsiveness is a primary determinant of the quality of the attachment relationship and therefore the behavioural tendencies of the developing child (Michiels, Grietens, Onghena, \& Kuppens, 2008).

\section{Parenting practices instead of parenting styles}

Identifying parenting variables predictive of children's academic attainment has been of great interest to researches (Cordy \& Wilson, 2004; Hill \& Craft, 2003; Peraita \& Pastor, 2000). In prior research, investigators have focused on parenting styles (such as responsiveness and demandingness), which generally tap into the emotional climate and parental control of parent-child interactions. Traditionally, there are two major dimensions of parenting styles that have been theoretically linked to pro-social and moral development (Carlo, McGinley, Hayes, Batenhorst, \& Wilkinson, 2007). The first is care and support which refers to the degree of positive affection present in parentchild relationships. The second is demandingness (or control), which refers to the degree of strictness and behavioural standards expressed by parents for their children. Many scholars have noted that parents who express high levels of responsiveness and care tend to be more child-centred and are more accepting of their children, have positive evaluations of their children, and foster close, interpersonal relationships with their 
children. The level of control is supportive to some extent and has been associated with lower levels of violent activity and with higher levels of academic motivation. (Carlo, McGinley, Hayes, Batenhorst \& Wilkinson, 2007; Frey, Ruchkin, Martin, \& SchwabStone, 2009).

However, there is growing interest in identifying specific parenting practices, rather than assessing general interaction styles, to better predict child's academic development and social behaviours. Parenting practices embrace both the basic characteristics of parenting styles as well as other variables such as open communication, instrumental and emotional support, indirect expressions of caring, parental control, and valued relationship qualities (Crockett, Brown, Russell, \& Shen, 2007).

\section{Parental control, monitoring and future confidence}

Personal motivation of learners, especially that of young children and adolescents, is heavily affected by their perceptions of the social and psychological environments that surround them, including home environment (Quing, Dawson-McClure, Sandier, Milisap, \& Woichik, 2008). Perceived expectations, pressures and support from parents, teachers and peers can cause students to feel confident or helpless, focus more strongly on a certain type of goal over others. Researchers have documented that achievement pressure from parents is a source of major stress and interferes with their coping (Bong, 2008). Therefore it is important to study future confidence and issues related to the future.

Monitoring, which refers to parent's awareness of child's activities and whereabouts, represents one aspect of parent-child control. Monitoring can occur in a broader range of situations (e.g., checking whether a child has completed homework, controlling child's attendance in hobby groups etc). High levels of parental monitoring may indicate that parents are interested and involved with their children. It has been associated with lower levels of juvenile delinquency and antisocial behaviour and better academic performance in middle childhood and adolescence (Kerns, Aspelmeier, Gentzler, \& Grabill, 2006). Conceptually speaking, there is a need to recognize the multi-dimensional nature of parental behavioural control (Shek, 2006) and to differentiate between parental monitoring and parental knowledge of children's activities.

\section{Family activities}

Discussions about family activities are always closely related to the term quality time. Quality time spent together with the family and common activities create a basis for child's successful coping in the future. There are remarkable differences on parents' views of quality time (Snyder, 2007): (1) structured-planning parents saw it as planned family activities, (2) child-centred parents emphasized heart-to-heart talks with their children and (3) time-intensive parents believed that all the time they spent with their families was quality time.

The current article focuses on some aspects of parenting practices studying the level of care in families, children's future expectations in the context of parental control, family activities and children's hobbies as an indicator of parental control and/or parental knowledge of children's activities. The current article is based on the following research 
question: How do students and parents understand family care, joint family activities, and vision of future and do their conceptions differ?

During the current academic year 2008/2009 there are 147.519 students studying in Estonian general education schools, of which $75 \%$ are Estonians and $25 \%$ of other nationalities, mostly Russians (Õpilaste arv... 2008). When planning the current study in 2002/2003, there were 200.478 students studying in Estonian general education schools, which is considerably more compared to the present time, however, the percentage of Russian speaking students has remained $25 \%$. Thus, to have an adequate overview of students' opinions, we considered it important to include also Russian speaking students and their parents in the current study.

\section{The goal}

Taking into account the aforementioned theoretical viewpoints, the current study aims to find out how Estonian and Russian speaking students from the II and III levels of basic school and from gymnasium and their parents evaluate their family relations, family activities, and what expectations they have for the future. There are several problems concerning children's coping in Estonia (e.g. high dropping out rate) and therefore many researches have focused on aspects having effect on it. The research "Kool kui arengukeskkond ja õpilaste toimetulek" (School as a developmental environment and students' coping) carried out in Estonia in 2005-2007 also embraced different aspects influencing students' coping, including the role of families and their partnership with schools. The results revealed significant differences between studied ethnic groups (Russian students were more concerned about their studies and academic performance than Estonian students, and Russian parents were better informed about their child's school) (Veisson, Kallas, Leino, Ruus, \& Veisson, 2008).The research supported the necessity for a deeper study of families and their dynamics especially in the framework of ethnic differences. Arising from that the current study had the following bypotheses:

1. The importance of interpersonal relations in families is different between two main ethnic groups - Estonian and Russian (Russian families value closer interpersonal relations more than Estonian families);

2. Estonian speaking students and their parents are less worried about their future than Russian students and their parents.

\section{Method}

The current study is based on the results of the state financed project of the Department of Educational Sciences of Tallinn University "School as developmental environment and students' coping”*, which main aim was to study students' coping at school and dropping out.

The questionnaires, which were distributed to students from $4^{\text {th }}$ through $12^{\text {th }}$ grades and to parents, comprised 53 questions. Corresponding to the language of conduct at school, the questionnaires were created in Estonian and in Russian. 


\section{Participants}

The study included 3838 students from $7^{\text {th }}-12^{\text {th }}$ grades from Estonian general education schools and 2048 parents. The second part of the study included 534 students from $4^{\text {th }}$ $6^{\text {th }}$ grades and their 357 parents.

\section{Design}

The sample was created with the aim to include: 1) schools with Estonian or Russian as the languages of conduct, 2) city and country schools and 3) schools with ranging academic success according to the state exam results of the past 5 years. Altogether 66 general education schools from different parts of Estonia participated. The study was carried out in 2004-2007.

\section{Procedure}

The current study had two phases. The first part included students from grades 7-12 and their parents and took place in 2004-2005. The second phase in 2006-2007 included students of grades 4-6 of the same schools and their parents.

\section{Results}

Several significant differences between Estonian and Russian speaking students' as well as their parents' appraisals about the future, family activities, caring and extracurricular activities were found.

\section{Students' and parents' evaluations about the future}

Younger Estonian students' appraisals about their future are more positive compared to Russian students. The fear of not finishing the school is somewhat bigger in case of Estonian students. Russian students, however, have more reason to worry about behavioural problems. In general, students of the younger school level are more positive, believe that they are able to finish the school, that they will not have many problems because of behaviour, and that this is also not a reason for dropping out of school (Table1).

Younger Russian students worry more about going to university and about combining family and work life. Estonian students in turn worry more about being unemployed.

Table 1. 4-6 grade students' evaluations about their future

\begin{tabular}{|c|c|c|c|c|c|}
\hline \multirow[t]{2}{*}{ When thinking about the future ... } & \multicolumn{2}{|c|}{ Estonian \% } & \multicolumn{2}{|c|}{ Russian \% } & $* *$ \\
\hline & Yes & No & Yes & No & \\
\hline $\begin{array}{l}\text { 1. ...I believe I will always do well at school } \\
(\text { Estonian } \mathrm{n}=168 ; \text { Russian } \mathrm{n}=180)\end{array}$ & 85.1 & 14.9 & 82.7 & 17.2 & .000 \\
\hline $\begin{array}{l}\text { 2. ...I am afraid that I won't be able to finish } \\
\text { school (Estonian } \mathrm{n}=170 ; \text { Russian } \mathrm{n}=177 \text { ) }\end{array}$ & 14.1 & 85.9 & 13.6 & 86.4 & .000 \\
\hline
\end{tabular}


Sequel to Table 1.

3. ...I believe I won't have problems because of my behaviour (Estonian $\mathrm{n}=167$; Russian $\mathrm{n}=178$ )

$\begin{array}{lllll}73.0 & 27 & 72,2 & 28.7 & .000\end{array}$

4. ...I am afraid that I will drop out of school

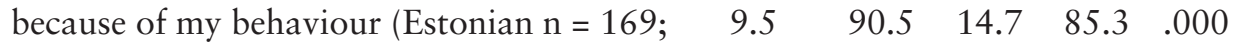
Russian $\mathrm{n}=177$ )

5. ...I am afraid I will not continue my studies at the university (Estonian $\mathrm{n}=169$; $\begin{array}{lllll}20.2 & 79.8 & 21.6 & 78.4 & .000\end{array}$ Russian $\mathrm{n}=176$ )

6. ...I am sure I won't be unemployed

$\begin{array}{lllll}87.3 & 12.6 & 90.0 & 10.0 & .007\end{array}$
(Estonian $\mathrm{n}=166$; Russian $\mathrm{n}=170$ )

7. ...I am afraid I won't be able to combine work with family life (Estonian $\mathrm{n}=168$; Russian $\mathrm{n}=175$ )

$*$ The differences are significant at $p<.001$

It appears that older Estonian students are more confident about succeeding at school compared to older Russian students. Students of higher grades are in general more selfassured about their behaviour and believe that they won't have problems because of that. Estonian speaking students worry more about not being able to continue their studies at the university. Being unemployed worries more Russian than Estonian students (Table 2). When comparing the evaluations about the future of Estonian and Russian students on both school levels, it appeared that older Russian students feel more uncertain about their abilities to do well at school and worry much more about their chances to find work in future.

Table 2. 7-12 grade students' evaluations about their future

\begin{tabular}{|c|c|c|c|c|c|}
\hline \multirow[t]{2}{*}{ When thinking about the future ... } & \multicolumn{2}{|c|}{ Estonian \% } & \multicolumn{2}{|c|}{ Russian \% } & \multirow[t]{2}{*}{$* *$} \\
\hline & Yes & No & Yes & No & \\
\hline $\begin{array}{l}\text { 1. ... I believe I will always do well at school } \\
(\text { Estonian } \mathrm{n}=2553 \text {; Russian } \mathrm{n}=778)\end{array}$ & 84.7 & 15.3 & 72.1 & 27.9 & .000 \\
\hline $\begin{array}{l}\text { 2. ...I am afraid that I won't be able to finish } \\
\text { school (Estonian } \mathrm{n}=2543 \text {; Russian } \mathrm{n}=786 \text { ) }\end{array}$ & 19.7 & 80.4 & 15.4 & 84.6 & .000 \\
\hline $\begin{array}{l}\text { 3. ...I believe I won't have problems because } \\
\text { of my behaviour (Estonian } \mathrm{n}=2529 \text {; } \\
\text { Russian } \mathrm{n}=775 \text { ) }\end{array}$ & 77.5 & 22.5 & 75.6 & 30.7 & .000 \\
\hline $\begin{array}{l}\text { 4. ...I am afraid that I will drop out of school } \\
\text { because of my behaviour (Estonian } n=2544 \text {; } \\
\text { Russian } n=780 \text { ) }\end{array}$ & 6.3 & 93.8 & 12.1 & 87.9 & .000 \\
\hline $\begin{array}{l}\text { 5. ...I am afraid I will not continue my studies } \\
\text { at the university (Estonian } \mathrm{n}=2534 \text {; } \\
\text { Russian } \mathrm{n}=775 \text { ) }\end{array}$ & 41.6 & 58.3 & 26.7 & 73.3 & .000 \\
\hline
\end{tabular}


Sequel to Table 2.

6. ...I am sure I won't be unemployed

$\begin{array}{lllll}73.7 & 26.3 & 17.8 & 82.1 & .000\end{array}$ (Estonian $\mathrm{n}=2483$; Russian $\mathrm{n}=749$ )

7. ... I am afraid I won't be able to combine work with family life (Estonian $\mathrm{n}=2523$; Russian $\mathrm{n}=776$ )

\section{$\begin{array}{lllll}13.1 & 86.8 & 12.2 & 87.7 & .000\end{array}$}

$* *$ The differences are significant at $p<.001$

When analysing parents' appraisals (in case of parents the questionnaire included four items; cf. Table 3 ) between the school levels with the $\chi^{2}$-test a statistically significant difference $(p<.001)$ appeared between $7-12$ grade students $(n=3838)$ and their parents' $(\mathrm{n}=2048)$ responses, except for one item: won't have problems with teachers because of behaviour ( $p<.000 ; .000 ; .052 ; .000$ respectively).

Parents evaluate their child's future more positively as students themselves. Of older students $38.1 \%$ are not afraid that they will drop out school, whereas of parents $56.9 \%$ do not worry about this. Thus, students' fears concerning finishing school are significantly higher compared to their parents.

Comparing the responses of $4-6$ grade students $(n=534)$ and their parents $(\mathrm{n}=357)$, there were statistically significant differences $(p<.005)$ in case of all 4 items $(p<.05 ; .002 ; .05 ; .001$ respectively).

Worries about finishing school are in case of younger students smaller, however here too parents' evaluations are more positive $(48.1 \%$ of students do not believe that they will have problems with finishing school compared to $61 \%$ of the parents).

Thus, parents of both younger and older students worry less about their children not finishing school than students themselves. There can be several reasons for this. On the one hand, parents may be more optimistic, because they are not familiar with all the problems at school. On the other hand, parents in general are hopeful and positive that their children will manage in future (Table 3).

Table 3. Parents' evaluations about their child's future

\begin{tabular}{|c|c|c|c|c|c|}
\hline \multirow[t]{2}{*}{ When thinking about the future ... } & \multicolumn{2}{|c|}{ Estonian \% } & \multicolumn{2}{|c|}{ Russian \% } & \multirow[t]{2}{*}{$* \%$} \\
\hline & Yes & No & Yes & No & \\
\hline $\begin{array}{l}\text { 1. ...I believe I will always do well at school } \\
\text { (Students } n=4315 \text {; Parents } n=2324)\end{array}$ & 82.1 & 17.9 & 82.8 & 17.3 & .000 \\
\hline $\begin{array}{l}\text { 2. ...I am afraid that I won't be able to finish } \\
\text { school (Students } n=4307 \text {; Parents } n=2252 \text { ) }\end{array}$ & 18.0 & 82.1 & 9.4 & 90.6 & .000 \\
\hline $\begin{array}{l}\text { 3. ... I believe I won't have problems because } \\
\text { of my behaviour ( } \text { Students } n=4271 \text {; } \\
\text { Parents } n=2273 \text { ) }\end{array}$ & 74.7 & 25.3 & 77.0 & 23.1 & .027 \\
\hline $\begin{array}{l}\text { 4. ... I am afraid that I will drop out of school } \\
\text { because of my behaviour (Students } n=4302 \text {; } \\
\text { Parents } n=2237 \text { ) }\end{array}$ & 8.2 & 91.7 & 4.4 & 95.7 & .000 \\
\hline
\end{tabular}




\section{Family activities}

When analysing Estonian and Russian students' appraisals to the frequency of family activities (scale options: almost never, some times per year, some times per moth, several times a week) statistically significant differences $(p<.005)$ appeared between 4-6 grade Estonian and Russian students in the following items: we talk about books, films or TV programs; we listen to classical music, whereas in Russian families such activities take place more often.

There were statistically significant differences $(p<.005)$ between $7-12$ grade Estonian and Russian students in the following items: we discuss political themes, we talk about books, films or TV programs, we listen to classical music, we talk about the school day, and we just talk and communicate. In case of older students too, such common family activities are more frequent in Russian families.

The only item in case of which there were no differences was eating together with the family. When comparing the results on different school levels, then both younger and older students gave relatively similar appraisals about the fact that their family members talk and communicate with each other frequently. Families of older students are less interested in their school day or eating together compared to younger students. In the opinions of older students (7-12 grades) their parents are not as interested in their school day as they would like them to be. According to 4-6 grade students' responses $80.1 \%$ of Estonian and $83.3 \%$ of Russian speaking parents asked about their child's school day several times a week, whereas in case older students these percentages were $65.9 \%$ and $73.1 \%$ respectively. It may be that in case of older students parents consider their children more independent and do not find it important to ask about the school day so frequently. The families of both older and younger Russian students show more interest in the school life compared to Estonian families.

\section{How caring families are}

There were statistically significant differences $(p=.05)$ in the appraisals of 4-6 and 7-12 grade students. Younger students considered their families to be more caring (Figure 1).

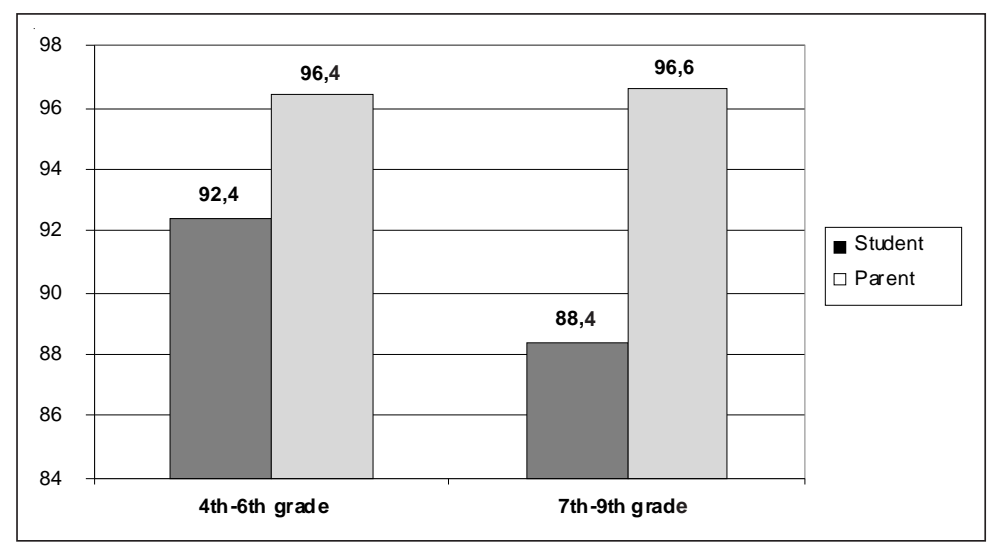

Figure 1. The comparisons of students' and their parents' appraisals about caring in families $(\%)$ on two school levels 
There were no statistically significant differences between the appraisals of parents of younger and older students. According to parents themselves, they care enough about their younger or older children. The significant differences in case of students, however, indicate that older students do not feel their families care enough about them and despite the fact that they are already "grown up," they need more attention and closeness in family relations. Other explanation can be that the elder ones are in the puberty period. They want to show independence and perhaps need another style of care. In general parents think that when the child is already in the basic school, he/she is independent enough and does not need as much closeness as younger children, however, especially in this age group students need support and caring, in order to cope with several problems, which they encounter.

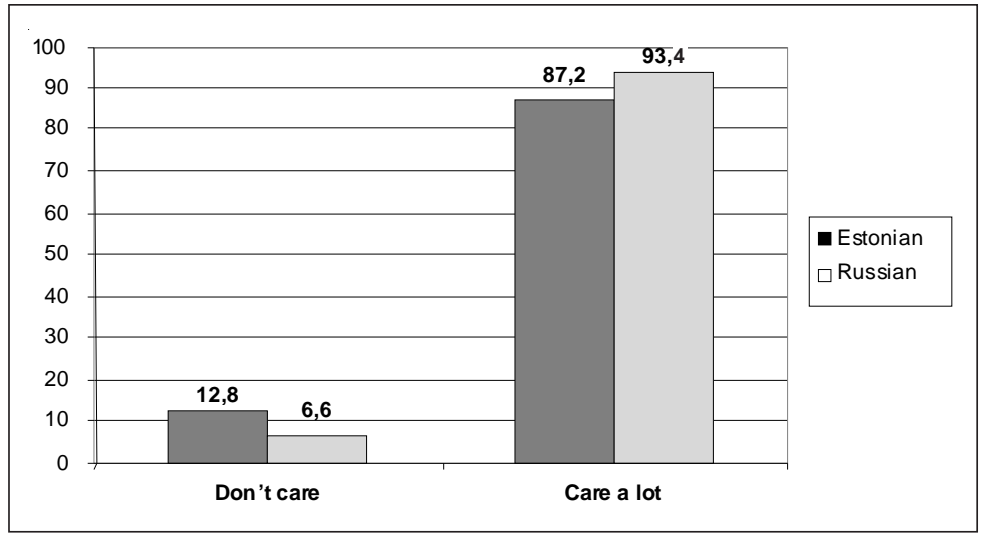

Figure 2. The appraisals of 7-12 grade Estonian and Russian language students about how caring their families are $(\%)$

There were no statistically significant differences in the appraisals of 4-6 grade Estonian and Russian students. In grades 7-12 Russian students appeared to be significantly more positive $(p<.001)$ in their appraisals (Figure 2$)$.

\section{Discussion}

Changes in family life have raised the question of quality in family relationships. Although the role of the family and parents continues to be meaningful in the context of children's coping, the actual loss of adult company in children's and young people's life (mostly due to the stressful working life) has led young people to the point, where they perceive family life as less important and families actually spend less and less time together.

Studying the families of two larger ethnical groups in Estonia - Estonians and Russians - revealed that Russian families tend to have a higher level of control and monitoring than Estonian families. When comparing different aspects of care and control, the results indicate that higher level of control do not necessarily mean more problems in Russian families, but rather that Russian families are more interested, involved, and more concerned about the future of their children.

Thus, both hypotheses of the current study were verified: Russian families value closer interpersonal relations than Estonian families and Russian students and parents 
are more concerned about their future than Estonians. In Russian families relations between children and parents are closer and more caring, parents talk, argue and discuss more frequently about various themes. Russian families appeared to care more and to get involved in planning their children's future rather early.

Parents' and students' concerns about future are rather different. In general students are more worried than parents, who are not always informed about all the problems students have to deal with at school. In case of older students communication with parents is not sufficient, thus parents might not evaluate the situation adequately enough and tend to overestimate the school. Similar results have been found in other studies elsewhere. Young people of all participating countries were similarly concerned about their future in the study of Gelhaar, Seiffge-Krenke, Borge, Cicognani, \& Cunha (2007), which compared problem-specific coping strategies and coping styles of European adolescents from seven nations: Croatia, the Czech Republic, Germany, Italy, Norway, Portugal and Switzerland.

The current study showed that Russian families spend more quality time together than Estonian families. Valuing family relations also helps to contribute to more healthy human relations in the future. The emotional support from parents that is one of the main characteristics of family activities may be seen as an important constitutive factor for child's sustainable development. If parents are unsupportive or insensitive to the child's signals or respond, they evoke a sense of insecurity in their child. Consequently, the child does not learn how to effectively interact and communicate with others (Michiels, Grietens, Onghena, \& Kuppens, 2008).

The results of the current study are consistent with other family studies. According to Realo and Allik (1999), who studied the questions of collectivism and individualism in Estonian, North American, and Russian populations, the Estonians are more individualistic than Russian people. Although the fact that the Russians living in Estonia were less collectivistic with regard to families and society than the Russians from Moscow corroborates the general rule that those who have migrated to other countries are usually more individualistic than those who have stayed in their resident countries. The Russian family values also dominated over the values of the individualism (Varlamova, Noskova, \& Sedova, 2008).

According to the study results the profile of parenting practices in Estonia is rather different for Estonian and Russian families. Russian families tend to struggle more to ensure their child's successful future, they have higher care and control levels and they pay more attention to good parent-child relationships. Estonian parents expect their children to cope themselves with their problems and challenges in life. However the results of the study do not give the whole picture of the aspects ensuring child's coping in future as it is mainly focused on quantitative characteristics. In order to provide an in-depth analysis of the differences of parenting practices supporting child's sustainable development, additional qualitative aspects as indirect expressions of caring and parental control, the nature of emotional support and communication should be considered.

The current article discusses main issues concerning the changes in families, showing the latest trends in parenting practices. Teacher education should provide their students with the knowledge based on the latest researches as the changes in our society are very rapid and therefore family studies form an important part of teacher education. According to the concept of holistic education, the broader is the network the child is living in, the stronger is its influence on child's development. Therefore cooperation between school 
and family creates more effective learning environment for a child. One of the most important bases is teacher training. Therefore it is essential to start from preparing the teachers who value home-school cooperation and have necessary skills for working with parents. Our lifestyle has become very stressfull and for parents it is increasingly difficult to find the time for activities other than just earning a living which means that it is schools' (teachers') responsibility to organize the work of parental involvement in the most effective way. That is why in teacher training programs more attention should be paid to introducing the principles of effective parental involvement (Lukk, 2008). The results of the study the article is based on and conclusion drawn from them indicate several important aspects teachers have to consider while working with parents. For example, as Estonian parents tend to worry less about their children's future and relationships in family and they focus more on their professional career, teachers who work with Estonian families should organize their work according to that (organize more activities based on the development of family values, to provide a special time for families to be together etc). Russian families in turn, with their strong bonding, are good partners for teachers and in problem solving teachers should involve them as an active part of the process. These are some examples how to implement the results of family studies in teaching process.

\section{References:}

Abelev, M. S. (2009). Advancing out of poverty: social class worldview and its relation to resilience. Journal of Adolescent Research, 24(1), 115-141. Retrieved February 10, 2009, from Academic Search Premier database.

Baum, A. C., \& Swick, J. K. (2008). Dispositions towards families and family involvement: Supporting pre-service teacher development. Early Childhood Education, $35,579-584$.

Bong, M. 2008. Effects of parent-child relationships and classroom goal structures on motivation, help-seeking avoidance, and cheating. The Journal of Experimental Education, 76(2), 191-217.

Bronfenbrenner, U. (2005). Making human being human: Bio-ecological perspectives on human development. Thousand Oaks, CA: Sage

Carlo, G., McGinley, M., Hayes, R., Batenhorst, C., \& Wilkinson, J. (2007). Parenting styles or practices? Parenting, sympathy and prosocial behaviors among adolescents. The Journal of Genetic Psychology, 168(2), 147-176.

Cordy, S., \& Wilson, J. D. (2004). Parents as first teachers. Education, 125(1). Retrieved November 1, 2005 from Academic Search Premier database.

Crockett, L. J., Brown, J., Russell, S. T., \& Shen, Y. (2007). The meaning of good parent-child relationships for Mexican American adolescents. Journal of Research on Adolescence, 17(4), 639-668.

Frey, A., Ruchkin, V., Martin, A., \& Schwab-Stone, M. (2009). Adolescents in transition: school and family characterstics in the development of violent behaviors entering high school. Child Psychiatry \& Human Development, 40(1), 1-13.

Gelhaar, T, Seiffge-Krenke, I., Borge, A., Cicognani, E., Cunha., Loncaric, D., Macek, P., Steinhausen, H. C., \& Metzke, C. (2007). Adolescent coping with everyday stressors: A seven-nation study of youth from central, eastern, southern, and northern Europe. European Journal of Developmental Psychology, 4(2), 129-156. 
Hill, N E., \& Craft, S. A. (2003). Parent school involvement and school performance: Mediated pathways among socioeconomically comparable African American and Euro-American families. Journal of Educational Psychology, 95(1), 74-83.

Kerns, K. A., Aspelmeier, J. E., Gentzler, A. L., \& Grabill, C. M. (2006). Parent-child attachment and monitoring in middle childhood. Journal of Family Psychology, 15(1), 69-81.

Liu, W., Wang, C. (2008). Home environment and classroom climate: An investigation of their relation to student's academic self-concept in a streamed settings. Current Psychology, 27(4), 242-256.

Lukk, K. (2008). Parental involvement in the framework of holistic education. In L. Ots (Ed.), School as developmental environment and students' coping (264-279). Tallinn: Tallinn University Press.

Mandolini, C. (2007). Condition, processes, and aims of teacher education: a philosophical perspective. Journal of Teacher Education for Sustainability, 7, 5-13.

Michiels, D., Grietens, H., Onghena, P., \& Kuppens, S. (2008). Parent-child interactions and relational aggression in peer relationships. Developmental Review, 28(4), 522540.

Peraita, C., \& Pastor, M. (2000). The primary school dropout in Spain: The influence of family background and labor market conditions. Education Economics, 8(2), 157-169.

Quing, Z., Dawson-McClure, S. R., Sandier, I. N., Milisap, R. E., \& Woichik, S. A. (2008). Mother-child relationship quality and effective discipline as mediators of the 6-year effects of the new beginnings program for children from divorced families. Journal of Consulting \& Clinical Psychology, 76(4), 579-594.

Realo, A. \& Allik, J. (1999). A cross-cultural study of collectivism: A comparison of American, Estonian and Russian students. The Journal of Social Psychology, 139(2), 133-142.

Shek, D. T. L. (2006). Perceived parent-child relational qualities and parental behavioral and psychological control in chinese adolescents in Hong Kong. Adolescence, 41(163), 563-581.

Snyder, K. A. (2007). A vocabulary of motives: understanding how parents define quality time. Journal of Marriage \& Family, 69(2), 320-340.

Stadelmann, S., Perren, S., Von Wyl, A., \& Von Klitzing, K. (2007). Associations between family relationships and symptoms/strengths at kindergarten age: What is the role of children's parental representations? Journal of Child Psychology \& Psychiatry, 48(10), 996-1004.

Turtiainen, P., Karvonen, S., \& Rahkonen, O. (2007). All in the family? The structure and meaning of family life among young people. Journal of Youth Studies, 10(4), 477-493.

Varlamova, S. N., Noskova, A., \& Sedova, N. N. (2008). Family and children in the attitudes and life plans of Russians. Russian Education and Society, 50(1), 6-28.

Õpilaste arv koolide ja filiaalide päevases õppevormis õppekeele ja klassi lõikes 2008/2009.(2008). Väljavõte EHIS-est seisuga 10. Nov. 2008. Retrieved February 14, 2009 from Estonian Ministry of Education and Research Database, http://www.hm.ee/index.php?47934 (A quantity of students in 2008/2009 in schools and branches of daily studies by language and grade) 
Veisson, M., Kallas, R., Leino, M., Ruus, V-R., \& Veisson, A. (2008). Differences and similarities of school culture, students' academic success, well-being, interests and coping in Estonian and Russian language general education schools in the Republic of Estonia. In L. Ots (Ed.), School as developmental environment and students' coping (165-194). Tallinn: Tallinn University Press.

*Data collection for the present study was funded by the Ministry of Education and Science in Estonia: the state financed project "School as a developmental environment and students' coping” (reg. no. 0132495s03).

\section{Correspondence:}

Monica Sakk, MA, doctoral student, Institute of Educational Sciences, Tallinn University, Uus-Sadama 5, Tallinn 10120, Estonia. Email: Monica.Sakk@tlu.ee 